\title{
Repression of Cathepsin D Expression in Adipocytes by MicroRNA-145
}

\author{
Hyun-Ji Kim ${ }^{1}$, In-Seon Bae ${ }^{1}$, Kang-Seok $\mathrm{Seo}^{2 *}$ and Sang Hoon $\mathrm{Kim}^{1 *}$ \\ ${ }^{1}$ Department of Biology, Kyung Hee University, Seoul 130-701, Korea \\ ${ }^{2}$ Department of Animal Science and Technology, Sunchon National University, Sunchon 540-950, Korea
}

Received April 22, 2014 /Revised July 15, 2014 / Accepted July 22, 2014

\begin{abstract}
Cathepsin D (CtsD), an aspartyl peptidase, is involved in apoptosis, resulting in the release of cytochrome $\mathrm{C}$ from mitochondria in cells. Here, we investigated microRNA regulation of $\mathrm{CtsD}$ expression in 3T3-L1 cells First, we observed the expression of CtsD in cells in response to doxorubicin (Dox). As expected, the level of CtsD mRNA was increased in 3T3-L1 cells exposed to Dox in a dose-dependent manner. Cellular viability of ectopically expressed CtsD cells was also decreased. Next, we used the miRanda program to search for particular microRNA targeting CtsD. MiR-145 was selected as a putative controller for CtsD because miR-145 had a high mirSVR score. In a reporter assay, the luciferase activity of cells containing the CtsD 3'-UTR region was decreased in cells transfected with miR-145 mimic compared to that of a control. The level of CtsD expression was down-regulated in preadipocytes ectopically expressing miR-145 and up-regulated by an miR-145 inhibitor. Cells also suppressed miR-145 expression when exposed to Dox. The miR-145 inhibitor reduced the cellular viability of3T3-L1 cells. Taken together, these data suggest that miR-145 regulates CtsD-mediated cell death in adipocytes. These findings may have valuable implications concerning the molecular mechanism of CtsD-mediated cell death in obesity, suggesting that $\mathrm{CtaD}$ could be a useful therapeutic tool for the prevention and treatment of obesity by regulating fat cell numbers.
\end{abstract}

Key words : 3T3-L1 cells, adipocytes, cathepsin, gene regulation, microRNA

\section{서 론}

비만은 제2형 당뇨병, 고혈압 등의 성인병을 유발하는 질병 으로 현대사회에서 인류의 건강을 위협하고 있다[10]. 비만은 세포생물학적 측면에서 지방전구세포에서 지방세포로 분화 된 세포의 수와 크기가 증가하여 발생한다[20]. 최근 비만 치료 와 관련한 연구는 지방전구세포의 사멸을 유도하거나 전사인 자의 제어를 통한 지방분화를 조절하는 방향으로 진행되고 있다[25]. 특히 지방전구세포의 사멸은 지방전구세포가 지방 세포로 전환되는 과정을 억제시키는 기전 중의 하나로 많은 연구가 진행되고 있다.

Cathepsin은 단백질 분해효소로 전구단백질의 크기는 30-50 kDa으로 골지체에서 인산화와 글리코실화 과정을 거쳐 리소좀에서 활성화된다[12]. Cathepsin family 중 Cathepsin $\mathrm{S}, \mathrm{K}, \mathrm{L}$ 은 지방분화와 관련이 있다. Cathepsin $\mathrm{S}$ 는 지방전구세

\footnotetext{
*Corresponding authors

Tel : +82-2-961-9208, Fax : +82-2-964-1079

E-mail : shkim@khu.ac.kr (Sang Hoon Kim)

Tel : +82-61-750-3232, Fax : +82-61-750-3230

E-mail : sks@suchon.ac.kr (Kang-Seok Seo)

This is an Open-Access article distributed under the terms of the Creative Commons Attribution Non-Commercial License (http://creativecommons.org/licenses/by-nc/3.0) which permits unrestricted non-commercial use, distribution, and reproduction in any medium, provided the original work is properly cited
}

포에서 지방분화를 촉진하고, 중성지방의 축적을 유도한다 [21]. Cathepsin K는 지방조직에서 발현이 높으며, Cathepsin $\mathrm{L}$ 은 비만 생쥐의 백색지방에서 많이 발현하고, Cathepsin L 발현을 억제하면 포도당 합성과 체중 감소가 유도되어 비만 마커 유전자로 활용 가능성이 제시되고 있다 $[3,24]$. Cathepsin $\mathrm{D}(\mathrm{CtsD})$ 는 종양세포에서 리소좀에 분포하는 단백질 분해효 소로서 세포질로 전이되어 apoptosis에 관여한다[6]. CtsD에 의한 세포사멸 유도는 Apaf-1과 상호작용하여 cytochrome C 를 미토콘드리아에서 세포질로 방출하여 caspase를 활성화시 킨다[15].

MicroRNA는 21-25개의 뉴클레오티드로 구성된 단일 염기 가닥의 small RNA로 진핵생물의 유전자 발현을 제어하는 생 물학적 활성을 나타낸다[13]. 지방세포에서 microRNA는 지 방분화, 인슐린 민감도, 지방대사에 관여한다 $[11,18]$. 지방분 화와 관련된 전사인자인 peroxidase proliferation activated receptor 8 는 miR-103, miR-107, miR-143 등의 microRNA 발 현을 조절하여 지방세포의 분화를 촉진한다[22, 23]. 본 연구에 서 $\mathrm{CtsD}$ 와 연관성이 있는 miR-145는 기존에 대장암 세포주에 서 STAT1 전사인자의 발현을 조절하여 세포 증식을 억제하는 종양억제 microRNA로 알려져 있다[8]. 그렇지만, 인체나 설 치동물의 지방전구세포에서 miR-145 역할은 아직 규명된 것 이 없다. 따라서, 본 연구에서는 지방전구세포에서 $\mathrm{CtsD}$ 의 역 할과 microRNA와의 연관성에 대해 조사하였다. 


\section{재료 및 방법}

\section{세포배양 및 세포 생존율 조사}

3T3-L1 지방전구세포는 American Type Culture Collection (ATCC, Manassas, VA, USA)에서 분양 받았으며, $10 \%$ calf serum과 $1 \%$ penicilin 및 streptomycin이 포함된 Dulbecco's modified Eagle's medium (DMEM) 배양액(WelGENE, $\mathrm{Daegu}, \mathrm{Korea}$ )을 사용하여 $37^{\circ} \mathrm{C}, 5 \% \mathrm{CO}_{2}$ 조건에서 배양하였 다. 세포 생존율을 조사하기 위하여 3T3-L1 세포를 96 well plate에 well 당 $1 \times 10^{3}$ 세포를 분주하여 안정화시킨 다음 lipofectamine reagent (Invitrogen, Carlsbad, CA, USA)을 사용 하여 사용법에 따라 $50 \mathrm{nM}$ 의 microRNA mimic을 세포에 도입 하고 24시간 더 배양하였다. 합성된 microRNA mimic은 GenePharma Inc. (Shanghai, China)에서 구입하였다. 24시간 이후 water-soluble tetrazolium salts (WST-1) 시약(Roche Diagnostics, Mannheim, Germany) $10 \mu$ 을 각 well에 첨가하 여 1시간 동안 반응시키고 VersaMax microplate reader (Molecular Devices, Sunnyvale, CA, USA)을 이용하여 440 $\mathrm{nm}$ 에서 흡광도를 측정하였다.

\section{Western blot analysis}

세포 추출물의 단백질 농도는 Bio-Rad Protein Assay kit (Bio-Rad, Hercules, CA, USA)을 이용하여 정량화하였으며, $40 \mu \mathrm{g}$ 단백질을 $10 \%$ sodium dodecyl sulfate-polyacrylamide gel electrophoresis으로 분리한 다음 nitrocellulose membrane으로 전이시키고 5\% skim milk를 함유한 blocking buffer와 반응시켰다. Membrane을 PBS로 세척한 후 anti-CtsD antibody (Abcam, Cambridge, MA, USA) 또는 actin antibody (Sigma, St. Louis, MO, USA)를 $4{ }^{\circ} \mathrm{C}$ 에서 16 시간 반응시 키고, 세척 후 rabbit IgG antibody (Sigma, St. Louis, MO, USA)에 1시간 더 반응시켰다. 항체에 반응한 단백질들은 WesternBright ECL kit (Advansta, Menlo Park, CA, USA)을 이용한 화학발광시스템으로 현상하여 관찰하였다.

\section{Real-time quantitative polymerase chain reaction (RT-qPCR)}

수거한 세포에 Trizol reagent (Invitrogen, Carlabad, CA, $\mathrm{USA}$ )을 반응시켜 total RNA를 분리하였다. 추출된 RNA를 Ultrospec 2100 pro (Amersham Biosciences, Uppsala, Swe$\mathrm{den}$ )을 이용하여 정량하고, 1ug RNA에 MMLV reverse-transcriptase (Promega, Madison, WI, USA)을 이용하여 cDNA를 합성하였다. CtsD mRNA 발현을 측정하기 위해 $\mathrm{CDNA}, \mathrm{SYBR}$ Green 2× PCR Master mix (M.Biotech Inc., Seoul, Korea)와 CFX94 real time system (Bio-Rad, Hercules, CA, USA)을 이 용하여 real-time $\mathrm{qPCR}$ 을 진행하였다. 특정 유전자를 증폭하 기 위한 $\mathrm{PCR}$ 조건은 $95^{\circ} \mathrm{C}$ 에서 15 초, $56^{\circ} \mathrm{C} 15$ 초, $72^{\circ} \mathrm{C} 15$ 초를
한 주기로 하여 40 cycle 동안 증폭하였다. CtsD mRNA 발현 량은 GAPDH 발현량으로 보정하였다. miR-145 발현 정도는 TaqMan MicroRNA assay (Applied Biosystems, Foster city, $\mathrm{CA}, \mathrm{USA}$ )를 이용하여 측정하였다. TaqMan reverse transcription kit (Applied Biosystems, Foster city, CA, USA)를 이용하여 100ng RNA에서 cDNA를 합성한 다음 miR-145 primer (Qiagen, Hilden, Germany)와 TaqMan Master mix kit (Applied Biosystems, Inc., Foster City, CA, USA)을 이용하여 CFX94 real time system으로 PCR을 수행하였다. PCR 조건은 $95^{\circ} \mathrm{C} 10$ 분 반응시킨 다음 $95^{\circ} \mathrm{C} 15$ 초, $60^{\circ} \mathrm{C} 1$ 분을 40 cycle 동안 실시하여 microRNA을 증폭하였다. 각 시료는 U6를 보정유전 자로 사용하였다.

\section{Luciferase 활성 분석}

CtsD 3' UTR 단편은 3T3-L1 지방전구세포로부터 cDNA를 합성한 다음 psiCHECK2 벡터 (Promega, Madison, WI, USA) 에 삽입하여 재조합 벡터 (psiCHECK-CtsD)를 구축하였다. COS7 세포주를 $4 \times 10^{4}$ cells/well로 분주하여 24 well plate에 서 배양하였다. CtsD 3'UTR을 함유한 psiCHECK-CtsD 벡터 와 miR-145 mimic을 lipofectamine 2000 (Invitrogen, Carla$\mathrm{bad}, \mathrm{CA}, \mathrm{USA}$ )을 사용하여 세포에 도입하였다. 2일간 배양한 후 세포를 용해시켜 dual luciferase assay kit (Promega, Madsion, WI, USA)를 이용하여 TD-20/20 Luminometer (Turner BioSystems, Sunnyvale, CA, USA)에서 luciferase 활 성을 측정하였다.

\section{통계 분석}

모든 자료의 통계 분석은 SPSS 18.0 (SPSS Inc., Chicago, IL, USA)을 사용하여 평균 및 표준편차를 산출하였다. Student's t-test로 유의성 검정을 실시하였다. 모든 실험은 독립적으로 3 회 이상 실시하여 통계 분석을 실시하였다.

\section{결과 및 고찰}

\section{CtsD에 의한 세포 생존율 조사 및 microRNA 선발}

$\mathrm{CtsD}$ 유전자는 종양세포에서 세포사멸에 관여하는 유전자 로 알려져 있지만,지방전구세포에서 $\mathrm{CtsD}$ 역할은 알려진 바 가 없다. 또한 $\mathrm{CtsD}$ 의 발현을 제어하는 microRNA에 대한 연 구도 아직 보고된 바가 없다. 따라서, 본 연구에서는 지방전구 세포에서 $\mathrm{CtsD}$ 발현을 조절하는 microRNA을 조사하고자 하 였다. 먼저, 지방전구세포의 사멸 시 CtsD 발현 변화를 관찰하 기 위하여 DNA damage agent인 doxorubicin (Dox)을 3T3-L1 세포주에 첨가하였다. 24시간 후 CtsD mRNA발현을 조사한 결과 농도의존적으로 발현이 증가하였다(Fig. $1 \mathrm{~A}) . \mathrm{CtsD}$ 발현 증가가 직접 세포사멸에 영향을 미치는지 조사하기 위하여 $\mathrm{CtsD}$ 유전자를 농도 차이를 주어 세포에 도입하였다. 그 결과, 
A

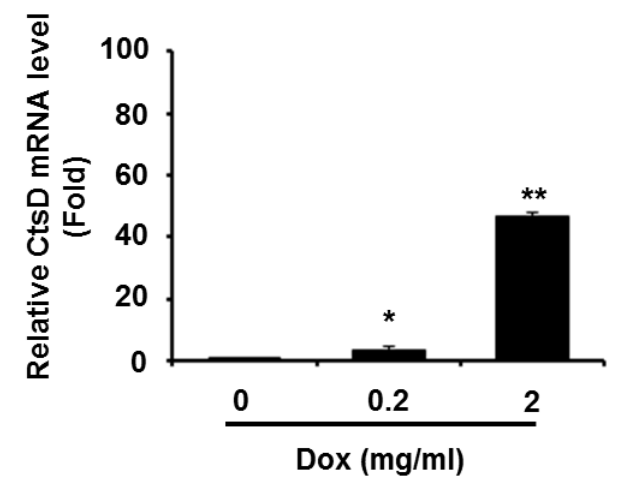

C

5' UCUCCACUGUCAGgGAACUGGAU 3' CtsD 3'UTR

III $|1||||| \mid$

3' UCCCUAAGGACCCUUUUGACCUG 5' miR-145
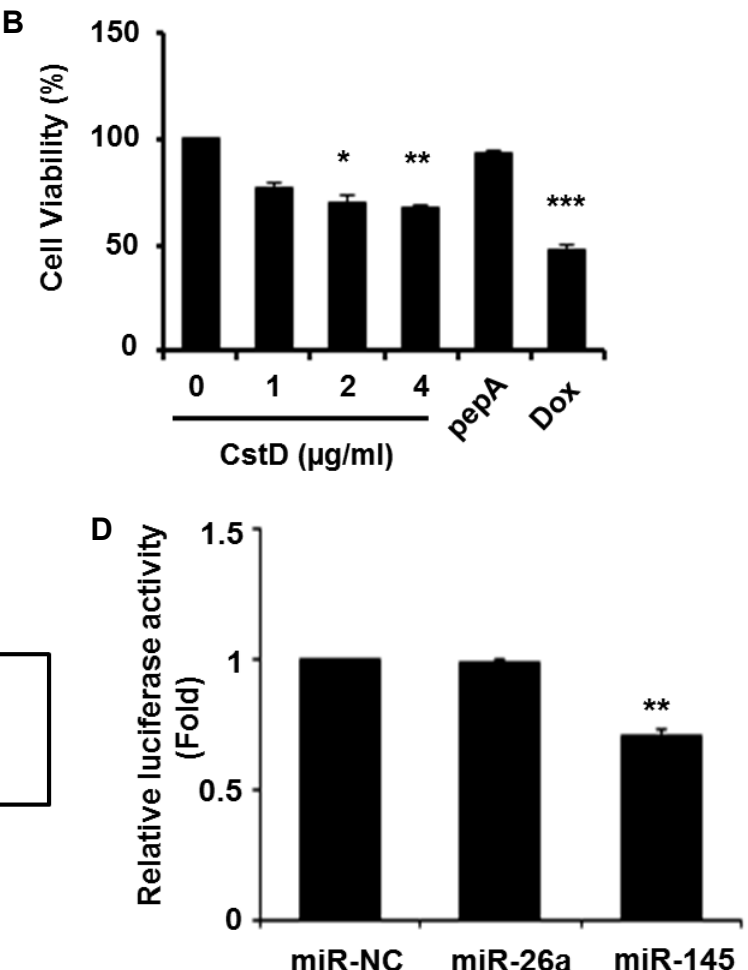

Fig. 1. Suppression of cellular viability in CtsD over-expressed cells. (A) Doxorubicin (Dox) was dose-dependently treated to 3T3-L1 cells. The CtsD level was determined by RT-qPCR after normalization with GAPDH. Values are means \pm SEM of triplicate. ${ }^{*} p<0.05$ versus control $\left(0 \mathrm{mg} / \mathrm{ml}\right.$ of Dox). ${ }^{* *} p<0.01$ versus control $(0 \mathrm{mg} / \mathrm{ml}$ of Dox $)$. (B) 3T3-L1 cells were transfected with the CtsD expression vector by dose-dependent manner. As control, CtsD inhibitor pestatinA (pepA) or Dox was treated into cells. At $24 \mathrm{hr}$ post transfection, cell viability was measured using a WST-1 assay. ${ }^{*} p<0.05$ versus control $(0 \mu \mathrm{g} / \mathrm{ml}$ of CtsD). ${ }^{* *} p<0.01$ versus control $\left(0 \mu \mathrm{g} / \mathrm{ml}\right.$ of CtsD). ${ }^{* * *} p<0.001$ versus control $(0 \mu \mathrm{g} / \mathrm{ml}$ of CtsD). (C) As a CtsD target microRNA, miR-145 was predicted by miRanda algorithm program. The miR-145 binding sites are resided at nucleotides 22-31 of CtsD 3'UTR. (D) For luciferase reporter assays, psiCHECK2 vector containing the full length CtsD 3'UTR was transfected with miR-145 mimic, miR-negative control (miR-NC) or miR-26a mimic in COS7 cells. The renilla luciferase activities were normalized with firefly luciferase activity. Data was expressed as a relative ratio to the miR-NC mimic. Values are shown as means $\pm \mathrm{SEM}, \mathrm{n}=3$. ${ }^{* *} p<0.01$ versus miR-NC.

Dox 약물을 처리한 세포의 생존율 감소 보다는 못했지만, 세 포내 CtsD plasmid의 농도가 증가할 수록 3T3-L1 세포주의 생존율도 점진적으로 줄어들었다(Fig. 1B). CtsD inhibitor인 pepstatin $\mathrm{A}(\mathrm{pepA})$ 가 첨가된 세포에서는 생존율에 큰 변화가 없었다. 이러한 결과는 $\mathrm{CtsD}$ 가 지방전구세포의 생존율에 직 접 영향을 미치고 있음을 나타낸다.

다음으로 세포생존과 관련있는 CtsD 유전자의 발현을 제어 하는 microRNA을 발굴하기 위해 miRanda program을 활용 하여 $\mathrm{CtsD} 3^{\prime} \mathrm{UTR}$ 에 결합하는 잠정적인 microRNA을 조사하 였다. 그 결과 2종의 microRNA (miR-22와 miR-145)가 microRNA support vector regression (mirSVR) 알고리즘에 의해 탐색되었다. 이 중 mirSVR score가 보다 높은 miR-145 (mirSVR score: -0.1846)을 선발하였다(Fig. 1C). 이를 토대로 CtsD 3' UTR 부위를 함유하는 psiCHECK reporter vector (psiCHECK$\mathrm{CtsD}$ )를 클로닝하여 miR-145와의 결합 여부를 luciferase reporter assay로 조사하였다. COS7 세포주에 psiCHECK-CtsD
벡터와 miR-145 mimic을 도입하여 luciferase 활성을 측정한 결과 microRNA negative control (miR-NC)에 비해 miR-145 mimic이 도입된 세포에서 luciferase 활성이 유의하게 감소하 였다(Fig. 1D). CtsD 유전자를 표적으로 사용하지 않는 miR26a mimic은 luciferase 활성에 큰 영향을 미치지 못했다. 따라 서, miR-145가 CtsD 유전자의 전사후 발현 조절에 직접 관여 하고 있음을 알 수 있다.

\section{$M i R-145$ 에 의한 CtsD mRNA 발현 제어 조사}

3T3-L1 세포주에서 miR-145에 의한 내인성 CtsD 유전자의 발현 변화를 조사하기 위해 RT-qPCR을 수행하였다. 지방전구 세포에 miR-145 mimic을 transfection한 후 miR-145의 세포내 도입여부를 확인하기 위해 miR-145 발현을 조사하였다. 그 결 과 miR-145 발현이 대조군(miR-NC)에 비해 7,000배 증가하여 세포내로 miR-145 mimic이 도입 되었음을 확인하였다. 도입 된 miR-145에 의한 CtsD mRNA 발현을 조사 결과 대조군 

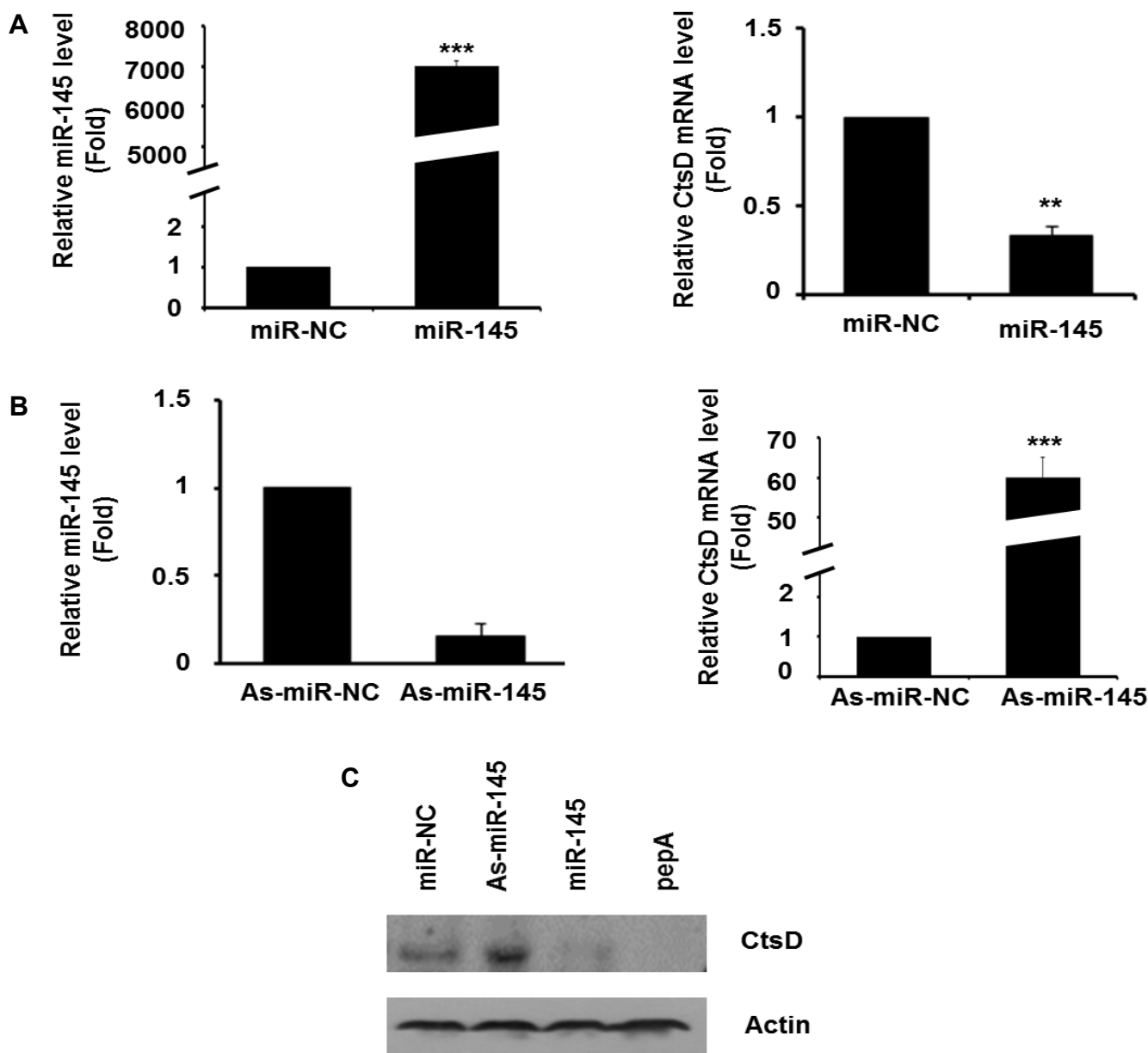

Fig. 2. The expression of CtsD in 3T3-L1 cells by miR-145. (A) 3T3-L1 cells were transfected with 50nM miR-NC or miR-145 mimic respectively. The levels of miR-145 and CtsD were determined by RT-qPCR. Values are means \pm SEM of triplicate. ${ }^{* *} p<$ 0.01 versus miR-NC. ${ }^{* * *} p<0.001$ versus miR-NC. (B) 3T3-L1 cells were transfected with As-miR-NC or As-miR-145 mimic for $24 \mathrm{hr}$. The expressions of miR-145 and CtsD were determined by RT-qPCR. Values are means \pm SEM of triplicate. *** $p<0.001$ versus miR-NC. (C) After transfection with miR-145 mimic, As-miR-145 mimic or miR-NC, cells were lysed and Western blot analysis was conducted with antibodies against CtsD and actin. Data are a representative example of 3 independent experiments.

(miR-NC)에 비해 발현이 75\% 감소하였다(Fig. 2A). 이외에도, miR-145 발현을 억제하는 miR-145 inhibitor (As-miR-145)을 세포주에 도입한 다음 발현을 조사한 결과 대조군(As-miR$\mathrm{NC})$ 에 비해 CtsD mRNA 발현이 대략 60배 이상 증가하였다 (Fig. 2B). 이러한 miR-145에 의한 CtsD mRNA 발현 변화가 $\mathrm{CtsD}$ 단백질에도 영향을 미치는지 조사하기 위해 Western blot을 실시하였다. 3T3-L1 세포주에 miR-NC가 도입된 경우 CtsD 단백질이 약하게 발현되고 있었으나, miR-145 inhibitor (As-miR-145)을 함유한 세포에서는 CtsD 단백질 발현이 증가 하였다. miR-145 mimic이 도입된 세포에서는 CtsD inhibitor 인 pepA가 처리된 세포와 유사하게 CtsD 단백질이 거의 감지 되지 않았다(Fig. 2C). 이러한 결과는 세포에서 miR-145가 $\mathrm{CtsD}$ 유전자의 발현을 직접 제어하고 있음을 나타낸다.

\section{$\mathrm{MiR}-145$ 에 의한 세포생존율 조사}

3T3-L1 세포주에서 Dox에 의한 CtsD 발현 증가를 관찰하 였기 때문에 이번에는 $\mathrm{CtsD}$ 유전자 발현을 억제하는 miR-145 의 발현을 조사하였다. 농도가 다르게 Dox을 지방전구세포에 처리하고 miR-145 발현을 관찰한 결과 CtsD mRNA 발현과 반대로 miR-145 발현이 농도 의존적으로 감소하였다(Fig. 3A). 또한 세포생존율도 miR-145 inhibitor (As-miR-145)가 도 입된 세포에서 대략 20\% 감소하였다(Fig. 3B). MiR-145 mimic 이 도입된 세포에서는 $\mathrm{CtsD}$ 발현여부와 관계없이 생존율에 변화가 없었으며, As-miR-145을 함유한 세포에서도 CtsD inhibitor인 pepA가 처리된 세포에서는 생존율에 차이가 없었 다.

이러한 결과를 종합하면 지방전구세포에서 miR-145가 $\mathrm{CtsD}$ 발현을 제어하여 세포 사멸을 억제할 수 있음을 알 수 

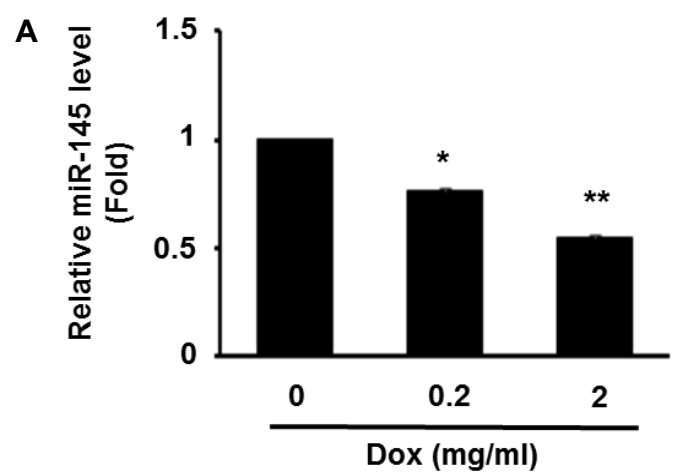

B

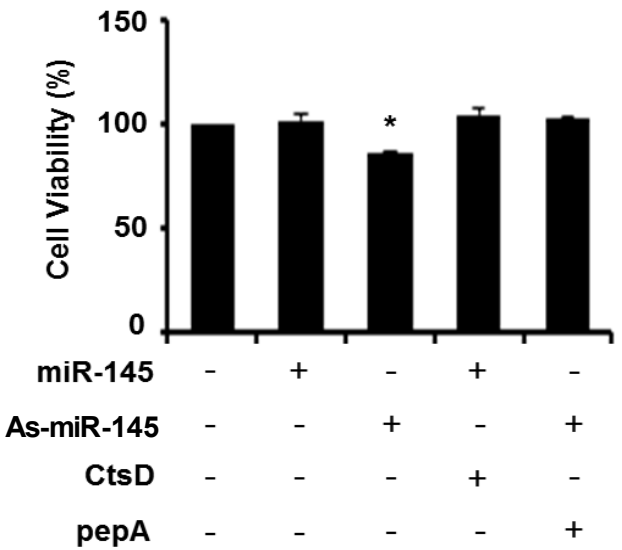

Fig. 3. Cell viability of 3T3-L1 cells exposed to miR-145. (A) The expression of miR-145 in cells treated with Dox was determined by RT-qPCR. Data are means \pm SEM of triplicate. ${ }^{*} p<0.05$ versus control $(0 \mathrm{mg} / \mathrm{ml}$ of Dox $)$. ** $p<0.01$ versus control $(0 \mathrm{mg} / \mathrm{ml}$ of Dox). (B) Cellular viability in 3T3-L1 cells was determined by WST-1 assay. Cells were transfected with the combination of miR-145 mimic, As-miR-145 mimic, CtsD vector, or pepA. Values are shown as means \pm SEM, $n=3$. ${ }^{*} p<0.05$ versus control (no treatment).

있다. 따라서 지방전구세포의 사멸을 유도하기 위해서는 miR145 발현 제어가 주요한 표적이 될 수 있을 것으로 생각된다. 기존 연구에 의하면 지방분화단계에서 miR-145 발현이 증가 하여 KLF4, KLF5, IRS1 등의 표적유전자 발현을 제어하는 것 으로 알려져 있다 $[2,9,16]$. KLF4와 KLF5는 zinc-finger protein으로 PPARr와 C/EBP 유전자를 활성화시켜 지방분화를 촉진시키고, IRS1은 인슐린에 의해 유도되는 지방분화과정의 중요한 매개자로 작용한다[1]. 즉, 지방분화시 miR-145는 지방 분화 제어를 통해 균형 있는 분화과정을 유도하기 위한 항상 성 유지에 중요한 역할을 하는 것으로 생각된다. 이외에도, human adipocyte에서 ADAM17은 miR-145의 표적유전자로 작용하여 세포내 TNF-a 경로를 활성화시켜 지방분해과정 (lipolysis)을 촉진시킨다[14]. TNF-a는 지방전구세포의 분화 를 억제하고, 지방세포의 apoptosis을 유도한다[17, 19]. 이러 한 지방분화과정에서와 달리 지방전구단계에서 miR-145 역할
은 아직 보고된 것이 없다. 따라서, 본 연구에서CtsD 유전자의 발현을 miR-145가 제어하여 지방전구세포의 세포사멸을 억제 시킬 수 있음을 보고하였다. 이러한 연구는 향후 비만 예방 및 치료를 위한 지방세포 사멸 기전을 규명하는데 중요한 실 마리를 제공할 수 있을 것으로 기대한다.

\section{감사의 글}

본 논문은 농촌진흥청 차세대 바이오그린21사업(과제번호 PJ008116)의 지원에 의해 이루어진 것임.

\section{References}

1. Ali, A. T., Hochfeld, W. E., Myburgh, R. and Pepper, M. S. 2013. Adipocytea and adipogenesis. Eur J Cell Biol 92, 229-236.

2. Birsoy, K., Chen, Z. and Friedman, J. 2008. Transcriptional regulation of adipogenesis by KLF4. Cell Metab 7, 339-347.

3. Chiellini, C., Costa, M., Novelli, S. E., Amri, E. Z., Benzi, L., Bertacca, A., Cohen, P., Del Prato, S., Friedman, J. M. and Maffei, M. 2003. Identification of cathepsin $\mathrm{K}$ as a novel marker of adiposity in white adipose tissue. J Cell Physiol 195, 309-321.

4. Conus, S., Perozzo, R., Reinheckel, T., Peters, C., Scapozza, L., Yousefi, S. and Simon, H. U. 2008. Caspase- 8 is activated by cathepsin $\mathrm{D}$ initiating neutrophil apoptosis during the resolution of inflammation. J Exp Med 205, 685-698.

5. Eguchi, A. and Feldstein, A. E. 2013. Lysosomal Cathepsin $\mathrm{D}$ contributes to cell death during adipocyte hypertrophy. Adipocyte 2, 170-175.

6. Emert-Sedlak, L., Shangary, S., Rabinovitz, A., Miranda, M. B., Delach, S. M. and Johnson, D. E. 2005. Involvement of cathepsin D in chemotherapy-induced cytochrome c release, caspase activation, and cell death. Mol Cancer Ther 4, 733742.

7. Cornicka, A., Fettig, J., Eguchi, A., Berk, M. P., Thapaliya, S., Dixon, L. J. and Feldstein, A. E. 2012. Adipocyte hypertrophy is associated with lysosomal permeability both in vivo and in vitro: role in adipose tissue inflammation. $A m$ J Physol Endocrinol Metab 303, E597-E606.

8. Gregersen, L. H., Jacobsen, A. B., Frankel, L. B., Wen, J., Krogh, A. and Lund, A. H. 2010. MicroRNA-145 targets YES and STAT1 in colon cancer cells. PLoS One 5, e8836.

9. Guo, Y., Chen, Y., Zhang, Y., Zhang, Y., Chen, L. and Mo, D. 2012. Up-regulated miR-145 expression inhibits porcine preadipocytes differentiation by targeting IRS1. Int J Biol SCi 8, 1408-1417.

10. Hajer, G. R., van Haeften, T. W. and Visseren, F. L. 2008. Adipose tissue dysfunction in obesity, diabetes, and vascular diseases. Eur Heart J 29, 2959-2971.

11. He, L. and Hannon, G. J. 2004. MicroRNAs: small RNAs with a big role in gene regulation. Nat Rev Genet 5, 522-531.

12. Im, E. and Kazlauskas, A. 2007. The role of cathepsins in 
ocular physiology and pathology. Exp Eye Res 84, 383-388.

13. Kim, V. N. 2005. MicroRNA biogenesis: coordinated cropping and dicing. Nat Rev Mol Cell Biol 6, 376-385.

14. Lorente-Cebrian, S., Mejhert, N., Kulyte, A., Laurencikiene, J., Astrom, G., Heden, P., Ryden, M. and Arner, P. 2014. MicroRNAs regulates human adipocyte lipolysis: effects of miR-145 are linked to TNF-alpha. PLOS One 9, e86800.

15. Minarowska, A., Minarowski, L., Karwowska, A. and Gacko, M. 2007. Regulatory role of cathepsin D in apoptosis. Folia Histochem Cytobiol 45, 159-163.

16. Oishi, Y., Manabe, I., Tobe, K., Tsushima, K., Shindo, T., Fujiu, K. et al. 2005. Kruppel-like transcription fator KLF5 is a key reguator of adipocyte differentiation. Cell Metab 1, 27-39.

17. Petruschke, T. and Hauner, H. 1993. Tumor necrosis factor-alpha prevents the differentiation of human adipocyte precursor cells and causes delipidtaion of newly developed fat cells. J Clin Endocrinol Metab 76, 742-747.

18. Poy, M. N., Spranger, M. and Stoffel, M. 2007. microRNAs and the regulation of glucose and lipid metabolism. Diabetes Obes Metab 9, 67-73.

19. Prins, J. B., Niesler, C. U., Winterfor, C .M., Bright, N. A., Siddle, K., O'Rahilly, S., Walker, N. I. and Cameron, D. P.
1997. Tumor necrosis factor-alpha induces apoptosis of human adipose cells. Diabetes 46, 1939-1944.

20. Prins, J. B. and O'Rahilly, S. 1997. Regulation of adipose cell number in man. Clin Sci (Lond) 92, 3-11.

21. Taleb, S., Cancello, R., Clement, K. and Lacasa, D. 2006. Cathepsin s promotes human preadipocyte differentiation: possible involvement of fibronectin degradation. Endocrinology 147, 4950-4959.

22. Trajkovski, M., Hausser, J., Soutschek, J., Bhat, B., Akin, A., Zavolan, M., Heim, M. H. and Stoffel, M. 2011. MicroRNAs 103 and 107 regulate insulin sensitivity. Nature 474, 649-653.

23. Xie, H., Lim, B. and Lodish, H. F. 2009. MicroRNAs induced during adipogenesis that accelerate fat cell development are downregulated in obesity. Diabetes 58, 1050-1057.

24. Yang, M., Zhang, Y., Pan, J., Sun, J., Liu, J., Libby, P., Sukhova, G. K., Doria, A., Katunuma, N., Peroni, O. D., Guerre-Millo, M., Kahn, B. B., Clement, K. and Shi, G. P. 2007. Cathepsin L activity controls adipogenesis and glucose tolerance. Nat Cell Biol 9, 970-977.

25. Zhang, Y. and Huang, C. 2012. Targeting adipocyte apoptosis: a novel strategy for obesity therapy. Biochem Biophys Res Commun 417, 1-4.

\title{
초록 : 지방세포에서 microRNA-145에 의한 Cathepsin D의 발현 제어
}

\author{
김현지 ${ }^{1} \cdot$ 배인선 $^{1} \cdot$ 서강석 $^{2 *} \cdot$ 김상훈 $^{1 *}$ \\ ( ${ }^{1}$ 경희대학교 생물학과, ${ }^{2}$ 순천대학교 동물자원과학과)
}

Cathepsin D (CtsD)는 아스파르트산 단백질 분해효소로서 cytochrome C의 방출을 유도하여 apoptosis 기전을 활성화시킨다. 본 연구에서는 3T3-L1 지방전구세포에서 CtsD 발현 조절에 관여하는 microRNA에 대해 조사하였 다. 먼저 지방전구세포 사멸시 CtsD 발현 변화를 관찰하기 위하여 DNA damage agent인 doxorubicin을 3T3-L1 세포주에 노출시켜 $\mathrm{CtsD}$ 발현이 증가함을 확인하였다. 또한 지방전구세포주에서 $\mathrm{CtsD}$ 가 과발현되면 세포 생존율 이 감소하였다. miRanda program을 이용하여 CtsD 유전자를 표적으로 하는 microRNA를 탐색하여 miR-145를 선 발하였다. Luciferase reporter assay에 의해 miR-145가 CtsD 유전자의 3' UTR 부위에 결합하여 luciferase 활성 을 감소시킴을 관찰하였다. 3T3-L1 세포주에 miR-145 mimic을 도입한 결과 CtsD mRNA 발현과 단백질 수준이 감소하였다. 또한 세포주에 doxorubicin을 처리한 결과 CtsD 유전자 발현 증가와 상반되게 miR-145 발현이 감소 하였다. 이외에도 miR-145 inhibitor을 세포에 도입하면 세포 생존율이 감소하였다. 이러한 결과는 지방전구세포 의 세포사멸에 CtsD가 관여할 수 있으며, miR-145에 의해 CtsD 발현이 직접 조절되고 있음을 나타낸다. 따라서, 지방전구세포의 사멸을 유도하기 위해서는 miR-145 발현 제어가 주요한 표적이 될 수 있을 것으로 생각된다. 본 연구결과는 향후 비만 예방 및 치료를 위한 지방세포 사멸기전 규명에 중요한 기초 자료를 제공할 수 있을 것으로 기대한다. 